\title{
ANAS SPONSA.
}

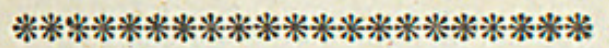

CHARACTER GENERICUS.

Rostrum lamelloso-dentatum, convexum, obtusum.

Linguce ciliata, obtusa.

$$
\text { Lin. Syst. Nat. }
$$

CHARACTER SPECIFICUS, E'C.

Anas crista variegata dependente, pectore castaneo albo-maculato, hypochondriis albo nigroque lunulatis.

Anas Sponsa. A. crista dependente duplici - viridi cæruleo alboque varia.

$$
\text { Lin. Syst. Nat. }
$$

In America tam septentrionali quam australi generatur formosissima hæc species; nec non in insulis nonnullis Indiæ occidentalis. Migrat huc illuc, mutata coeli temperie. Femina mare minor, fusca, subtus albida, nullo plumarum splendore superbit. 



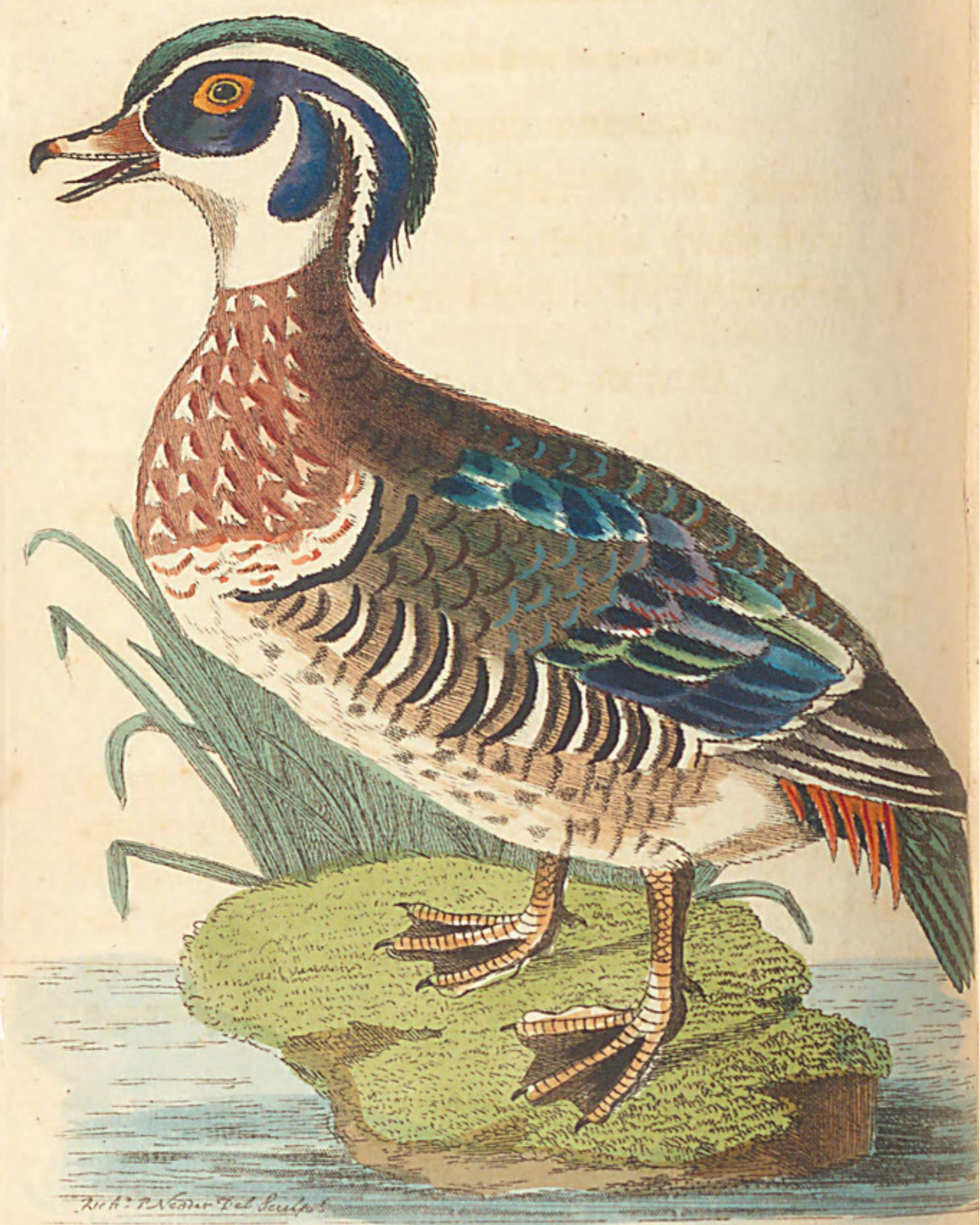




\section{SUMMER DUCK.}

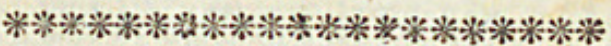

GENERIC CHARACTER.

Bill broad and flattened; the edges marked with sharp lamellæ.

Tongue broad, and ciliated at the edges.

\section{SPECIFIC CHARACTER, ${ }^{\circ}$ C.}

Duck with pendent variegated crest, chesnut breast spotted with white, and side-feathers lunulated with black and white.

The Summer Duck of Catesby.

Edw. pl. 101.

This most beautiful species is an inhabitant of many parts both of North and South America, migrating, according to the diversity of seasons, from one region to another. It is also found in some of the West Indian islands. The fernale is smaller, of a brown colour, and without any of that gaiety of plumage which so elegantly distinguishes the male. 


\section{$2 \mathrm{BHL}$ Biodiversity Heritage Library}

Shaw, George. 1813. "Anas sponsa, The Summer Duck [PI. 1037]." The Naturalist's Miscellany 24(CCLXXXI), -. https://doi.org/10.5962/p.322317.

View This Item Online: https://www.biodiversitylibrary.org/item/296719

DOI: https://doi.org/10.5962/p.322317

Permalink: https://www.biodiversitylibrary.org/partpdf/322317

\section{Holding Institution}

Museums Victoria

\section{Sponsored by}

Atlas of Living Australia

\section{Copyright \& Reuse}

Copyright Status: Public domain. The BHL considers that this work is no longer under copyright protection.

This document was created from content at the Biodiversity Heritage Library, the world's largest open access digital library for biodiversity literature and archives. Visit BHL at https://www.biodiversitylibrary.org. 